\title{
Sickled Erythrocytes Reversal and Membrane Stabilizing Compounds in Telfairia occidentalis
}

\author{
Samuel Atabo, ${ }^{1}$ Ismaila Alhaji Umar, ${ }^{1}$ Dorcas Bolanle James, ${ }^{1}$ and Aisha Indo Mamman ${ }^{2}$ \\ ${ }^{1}$ Department of Biochemistry, Ahmadu Bello University, Zaria, Nigeria \\ ${ }^{2}$ Department of Hematology, Ahmadu Bello University Teaching Hospital, Shika, Zaria, Nigeria \\ Correspondence should be addressed to Samuel Atabo; atabosam@yahoo.com
}

Received 6 December 2015; Revised 21 April 2016; Accepted 19 May 2016

Academic Editor: Timothy Wick

Copyright ( 2016 Samuel Atabo et al. This is an open access article distributed under the Creative Commons Attribution License, which permits unrestricted use, distribution, and reproduction in any medium, provided the original work is properly cited.

\begin{abstract}
Background and Purpose. Traditional management of sickle cell disease (SCD) is ubiquitous in Africa. In south-eastern Nigeria, Telfairia occidentalis (T. occidentalis) is strongly recommended for consumption by SCD patients, owing to its presumed therapeutic effect. This study investigates the antisickling and membrane regenerative potentials of T. occidentalis in sickled erythrocytes. Experimental Approach. Sickled erythrocytes obtained from SCD patients were treated with sodium metabisulphite (2\%) to induce further sickling. Heat and hypotonic-induced lyses of red blood cells' membranes were also carried out. The RBCs were treated with varying concentration $\left(10.0,1.0\right.$, and $0.1 \mathrm{mg} \mathrm{mL}^{-1}$ and $0.5,1.0,1.5,2.0$, and $2.5 \mathrm{mg} \mathrm{mL}^{-1}$, resp.) of T. occidentalis extracts as treatment regimen for in vitro antisickling and membrane stabilizing assays. Extract with peak activity was purified and reused in antisickling assay. Key Results. The antisickling activity of aqueous and methanolic extracts of leaves, seeds, and stem of Telfairia occidentalis at 10.0, 1.0, and $0.1 \mathrm{mg} \mathrm{mL}^{-1}$ revealed that the aqueous leaves extract $\left(10 \mathrm{mg} \mathrm{mL}^{-1}\right)$ exhibited the highest antisickling activity $(64.03 \%)$ which was significantly $(p<0.05)$ higher than that of the stem $(47.30 \%)$ and seeds $(37.50 \%)$. Partially purified fractions recorded improved antisickling effect (peak activity of 70\%). Characterization (using GC-MS) of the most active fraction revealed some bioactive compounds. In the membrane stabilizing assay, methanolic and aqueous stem extracts of T. occidentalis showed the highest effect of $71.85 \%$ and $61.29 \%$, respectively. Conclusions and Implications. The results provide scientific evidence for ethnopharmacological use of T. occidentalis in the management of SCD.
\end{abstract}

\section{Introduction}

Sickle cell disease (SCD) is a neglected tropical disease [1], and its global burden has continued to increase in lowand middle-income countries [2], especially in sub-Saharan Africa. It is a devastating genetic disorder affecting $2.3 \%$ of the world population, mainly in Africa [3], and responsible for about $2 \%$ death in children below the age of 5 in subSahara Africa [3]. In Nigeria, prevalence of SCA is about 2030 per 1000 births [3], and in June 19, 2012, the World Health Organization (WHO) reported that Nigeria has the highest number of sickle cell anaemia sufferers worldwide [4].

Various methods have been developed in an effort to find principles that prevent or reduce crises in SCD. Conventional medicines have achieved a great level of success in SCD management. In recent years, bone marrow transplantation has been found to be efficient in the treatment of SCD. However, the cost implications, unavailability of necessary expertise, and the problems of finding suitable donor constitute a major setback to this approach in developing countries [5]. In clinical practice, blood transfusion, Hydroxyurea, Hydroxycarbamide, Clotrimazole, and erythropoietin are used in SCD management, but the side effects of these drugs such as iron overload and mutagenic and teratogenic assertions limit their clinical use $[6,7]$.

On the understanding that herbal remedies and medicinal plant products from indigenous flora have long been used in traditional medicine for SCD management, it appears that proper and intense scientific investigations on these medicinal plants could be of remarkable help in developing effective and safer drugs for SCD treatment. Research on phytomedicine has led to the development of Nicosan (herbal based drug used to treat SCD). Other plants that have gained scientific backing as antisickling agents include Cajanus cajan 
$[8,9]$, Carica papaya [10-12], and Fagara zanthoxyloides [13, $14]$.

Telfairia occidentalis which has been linked to free radical scavenging, boosting of blood levels, and antiplasmodial and antimicrobial effects [15-17], is now being speculated in this study as a possible therapeutic agent for SCD management, owing to its consumption by SCD patients in south-eastern Nigeria.

\section{Materials and Methods}

2.1. Equipment, Chemicals, and Reagents. Some equipment used included Shimadzu GC-17A system, light microscope (Olympus CX 21), spectrophotometer (Jenway 6400), incubator (grant JB series), oven (Gallenkamp), and centrifuge (Labofuge 300). Chemicals such as Para-hydroxybenzoic acid (PABA) and sodium metabisulphite were procured from Sigma Chemical Company, Paderborn, Germany.

2.2. Collection and Extraction of Plant Materials. Fresh samples of Telfairia occidentalis were purchased from a farm in Kagarko local government area of Kaduna state. The plant was identified and authenticated at the Herbarium Unit, Biological Science Department, Ahmadu Bello University, Zaria, with a voucher specimen number 3252. Leaves, seeds, and stem of the plant were collected, shade-dried, and powdered using mortar and pestle. Each of the dried powdered material $(500 \mathrm{~g})$ was extracted with $2 \mathrm{~L}$ of methanol by cold maceration for 7 days in large amber bottles with intermittent shaking. At the end of the extraction, the crude methanolic extract was filtered using Whatman filter paper number 42 . The filtrate was concentrated by evaporation (using water bath at $45^{\circ} \mathrm{C}$ ). In another setup, dried powdered materials were soaked in distilled water for three days using the same proportion used for methanol extraction. It was overlaid with chloroform to prevent fermentation and bacterial degradation by inhibiting possible oxygen infiltration (i.e., $\mathrm{H}_{2} \mathrm{O}: \mathrm{CHCl}_{3}, 70: 30$ ). This was followed by evaporation to dryness to obtain aqueous extract. Filtrates obtained in both cases were reconstituted in normal saline.

2.3. Blood Collection, Ethical Approval, and Informed Consent. Blood $(2 \mathrm{~mL})$ was obtained by venipuncture from homozygous sickle cell disease (HbSS) patients in stable state at Ahmadu Bello University Teaching Hospital (ABUTH), Zaria. Approval by the Health Research Ethical Committee (HREC) and consent of participants were obtained in accordance with the ethical standards laid down in the 1964 Declaration of Helsinki.

2.4. Identification of Homozygous Sickle Cell Disease Patients. Differentiation of major genotypes method by hemoglobin electrophoresis technique was used.

The principle of hemoglobin electrophoresis (at alkaline $\mathrm{pH}$ 8.4-8.9) was based on charge change in hemoglobin molecules, which correlates with the rate of hemoglobin movement towards the anode.
Blood samples of different, but known, genotypes were spotted at the point of origin on the paper. It was then placed in the electrophoretic component containing a buffer system and connected to a source of current. Hemoglobin movement towards the anode (represented by hemoglobin bands) was peculiar to each genotype (HbAA, HbAS, HbSS, and HbSC). This was noted and was used as standard. Subsequent test samples were treated as mentioned above. Those that showed similar pattern of movement as HbSS (when compared with the standard) were obtained and used in this research.

2.5. Blood Preparation. The blood was placed in sodium ethylene diamine tetraacetic acid (EDTA) bottle and thoroughly mixed by gently rolling the bottle. Blood samples were used for the studies within $12 \mathrm{hrs}$ of collection.

2.6. Sample Size Determination. The minimum sample size in this study is determined by the formula of [18]:

$$
n=\frac{Z^{2} p q}{d^{2}}
$$

where $n$ is the minimum sample size, $Z$ is the value of the normal curve corresponding to $95 \%$ confidence interval, 1.96 , $p$ is the prevalence of sickle cell disease, $2.3 \%, q=1-p$, that is, $1-0.023=0.977, d$ is the level of significance or error margin, $5 \%$, and $n=1.96^{2} \times 0.023 \times 0.977 / 0.05^{2}=0.088 / 0.0025=$ 35.2 ; therefore, the minimum sample size was approximately 35.

2.7. Bioassay of Plant Extracts for Antisickling Activity. The bioassay of both methanolic and aqueous extracts of the plant materials for antisickling activity was carried out by measuring the level of reversal of sickled red blood cells (RBCs).

2.8. Evaluation of Antisickling Activity. Evaluation of antisickling activity was carried out according to the procedure of [19].

2.8.1. Principle. Washed erythrocytes were mixed with $2 \%$ sodium metabisulphite. Sodium metabisulphite initiates a decrease in oxygen tension thereby inducing the typical sickle shape of red blood cells. This is then followed by introduction of test extract in the test tube. The degree of reversal of sickling was measured by counting the number of cells unsickled under the light microscope.

2.8.2. Procedure. Half a milliliter $(0.5 \mathrm{~mL})$ of the washed erythrocytes was mixed with $0.5 \mathrm{~mL}$ of freshly prepared $2 \%$ sodium metabisulphite in a clean test tube. It was incubated in water bath at $37^{\circ} \mathrm{C}$ for 30 minutes. A drop of the mixture was then viewed under the microscope. Equal volumes $(0.5 \mathrm{~mL})$ each of normal saline and the extracts were added to the blood-metabisulphite mixtures in different test tube and incubated at $37^{\circ} \mathrm{C}$ for another 30 minutes. Aliquots were taken at 30 minutes intervals, for up to 2 hours.

The procedure described by [20] was used for smear preparation and counting of sickled and unsickled cells. 


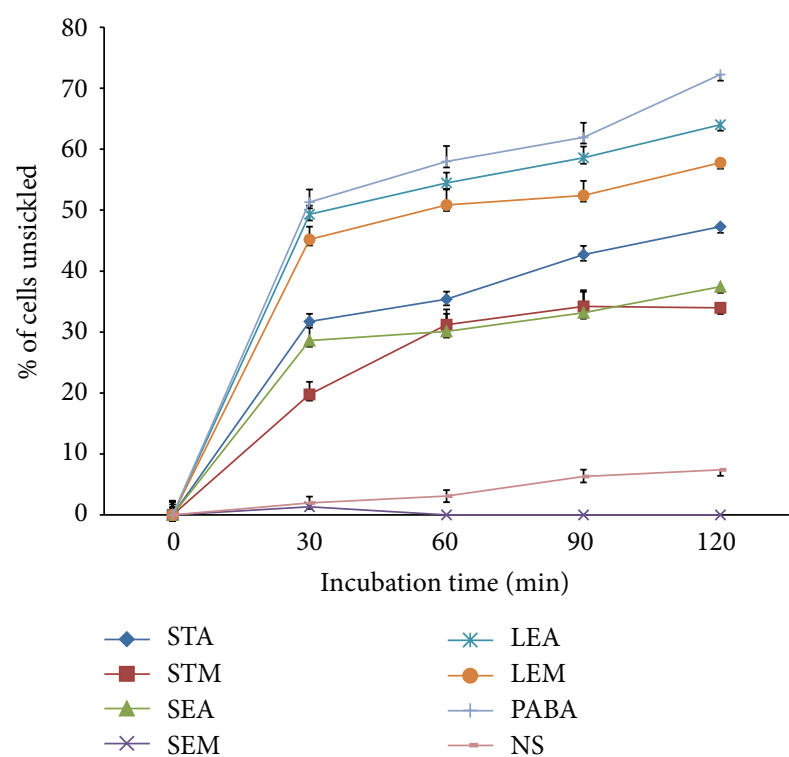

Figure 1: Percentage cells unsickled with time by $10 \mathrm{mg} \mathrm{mL}^{-1}$ extracts of leaves, seeds, and stem. LEA: aqueous leaves extract, LEM: methanolic leaves extract, SEA: aqueous seed extract, SEM: methanolic seeds extract, STA: aqueous stem extract, STM: methanolic stem extract, NS: normal saline, and PABA: Parahydroxybenzoic acid.

Briefly, each sample was smeared on microscope slide, fixed with $95 \%$ methanol, dried, and stained with Giemsa stain. It was then examined under an oil immersion microscope and counting red blood cells was carried out by viewing from different fields (4 fields) across the slide. The numbers of both sickled and unsickled red blood cells were counted and the percentage of cells unsickled was determined (Figure 1).

It was calculated by the following formula:

Percentage of cells unsickled

$$
=\frac{\text { Number of cells unsickled }}{\text { Total number of sickled cells }} \times 100 \text {. }
$$

2.9. Antisickling Experimental Control. P-Hydroxybenzoic acid $\left(5 \mathrm{mg} \mathrm{mL}^{-1}\right)$ and normal saline were, respectively, employed as positive and negative controls.

2.10. Membrane Stabilizing Activity. The membrane stabilizing assay method was based on the procedure described by [21].

The assay mixture consisted of $2 \mathrm{~mL}$ of $0.25 \%(\mathrm{w} / \mathrm{v}) \mathrm{NaCl}$, $1.0 \mathrm{~mL}$ of $0.15 \mathrm{M}$ sodium phosphate buffer ( $\mathrm{pH} 7.4$ ), $0.75 \mathrm{~mL}$ of various concentrations $\left(0.5,1.0,1.5,2.0\right.$, and $\left.2.5 \mathrm{mg} \mathrm{mL}^{-1}\right)$ of plant extracts, and $0.5 \mathrm{~mL}$ of $(2 \% \mathrm{v} / \mathrm{v})$ erythrocyte suspension. The control was prepared as mentioned above, but without drug or extract (blood control), while the drug control was without extract. The standard drugs used were Indomethacin and Ibuprofen. The reaction mixtures were incubated at $56^{\circ} \mathrm{C}$ for 30 minutes, cooled under running water, and then centrifuged at $3913 \times \mathrm{g}$.
The principle behind this assay is the spectrophotometric measurement of the amount of hemoglobin released (read at $560 \mathrm{~nm}$ ) by sickled erythrocytes, which is dependent on the extent of stabilization of sickled red blood cells' membrane exerted by the test extract.

The percentage membrane stability was estimated thus:

$\%$ Membrane stability

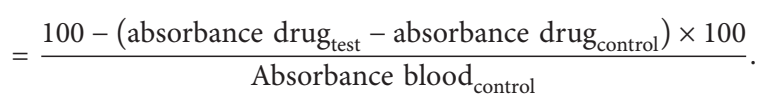

2.11. Thin Layer Chromatography (TLC). Commercially prepared TLC aluminum sheets $(20 \mathrm{~cm}$ by $20 \mathrm{~cm}$ ) lined with silica gel were used. The plate was cut to fitted size of $5 \times$ $5 \mathrm{~cm}$. The extract was dissolved in $95 \%$ methanol and spotted at the bottom of the TLC plate (about $0.5 \mathrm{~cm}$ from the base) using a micro haematocrit capillary tube. The plate was placed in a chromatographic tank and eluted with a mixture of different solvents. The gradient mixture of hexane and ethyl acetate mixture gave the best resolution. Hexane/ethyl acetate at different ratios $(100 \%$ hexane $9: 1 \mathrm{v} / \mathrm{v}, 8: 2 \mathrm{v} / \mathrm{v}, 7: 3 \mathrm{v} / \mathrm{v}$, $6: 4 \mathrm{v} / \mathrm{v}, 5: 5 \mathrm{v} / \mathrm{v}, 4: 6 \mathrm{v} / \mathrm{v}, 3: 7 \mathrm{v} / \mathrm{v}, 2: 8 \mathrm{v} / \mathrm{v}, 1: 9 \mathrm{v} / \mathrm{v}$, and $100 \%$ ethyl acetate) was used. The plate was then removed, airdried, and developed by spraying with $10 \%$ sulphuric acid in methanol. It was viewed under UV light. Spots, where seen, hence adjudged the solvent system of choice for use in column chromatography.

2.12. Partial Purification of Crude Extract (Column Chromatography). Partial purification of active crude extracts using a modified method of [22] was employed. In this method, the crude extract of T. occidentalis was separated using silica gel (as adsorbent, 70-230 mesh) packed in a chromatographic column. The adsorbent was overlaid with cotton wool before and after the application of plant extract. The cotton wool is to prevent direct contact or mixing of extract with the silica gel, to absorb shock (that may cause crack in the loaded adsorbent) when solvent is being poured into the chromatographic column, and to serve as filter for particles that may lurk within the solvent. Slurry of powdered silica gel in hexane was packed in glass column $(50 \mathrm{~cm})$ to a height of about $12 \mathrm{~cm}$ (and diameter of $3 \mathrm{~cm}$ ). It was then loaded with $10 \mathrm{~mL}$ of extracts dissolved in methanol and separated by gradient elution with solvent system of choice $(100 \%$ hexane $9: 1 \mathrm{v} / \mathrm{v}, 8: 2 \mathrm{v} / \mathrm{v}, 7: 3 \mathrm{v} / \mathrm{v}, 6: 4 \mathrm{v} / \mathrm{v}, 5: 5 \mathrm{v} / \mathrm{v}, 4: 6 \mathrm{v} / \mathrm{v}$, $3: 7 \mathrm{v} / \mathrm{v}, 2: 8 \mathrm{v} / \mathrm{v}, 1: 9 \mathrm{v} / \mathrm{v}$, and $100 \%$ ethyl acetate) at different proportion and in order of their increasing polarity. Fractions $(10 \mathrm{~mL})$ were collected into different labeled beakers. The solvent was allowed to evaporate and the content spotted on TLC chromatographic sheet to view the level of resolution on the basis of spots. Fractions that showed the same number of spots and the same colour and retention factor $\left(R_{f}\right)$ values were pulled together and used for antisickling assay.

2.13. Characterization of Purified Fraction. The purified fraction that showed peak antisickling activity was characterized using Gas Chromatography linked Mass Spectroscopy (GCMS). The fraction was dissolved in methanol and applied on a 
TABLE 1: Peak antisickling effect of crude aqueous and methanolic extracts of Telferia occidentalis (fluted pumpkin) leaves, seeds, and stem.

\begin{tabular}{lccr}
\hline Crude extract & & \% of cells unsickled at 120 min & $0.1 \mathrm{mg}$ \\
\hline LEA & $10 \mathrm{mg}$ & $60.59 \pm 1.60^{\mathrm{b}, 5}$ & $55.45 \pm 1.46^{\mathrm{a}, 5}$ \\
LEM & $64.03 \pm 1.69^{\mathrm{c}, 5}$ & $50.82 \pm 1.18^{\mathrm{b}, 4}$ & $46.11 \pm 1.72^{\mathrm{a}, 4}$ \\
STA & $57.79 \pm 2.61^{\mathrm{c} 4}$ & $43.69 \pm 3.20^{\mathrm{b}, 3}$ & $32.79 \pm 1.80^{\mathrm{a}, 3}$ \\
STM & $47.33 \pm 2.11^{\mathrm{b}, 3}$ & $26.51 \pm 1.52^{\mathrm{b}, 1}$ & $15.36 \pm 0.41^{\mathrm{a}, 1}$ \\
SEA & $33.98 \pm 1.54^{\mathrm{c}, 1}$ & $31.35 \pm 1.20^{\mathrm{b}, 2}$ & $27.48 \pm 1.23^{\mathrm{a}, 2}$ \\
SEM & $37.45 \pm 1.16^{\mathrm{c}, 2}$ & - & $36.23 \pm 3.70$ \\
\hline
\end{tabular}

Values in the same row with different superscripts $(\mathrm{a}-\mathrm{c})$ are significantly different at $p<0.05$.

Values in the same column with different superscripts (1-5) are significantly different at $p<0.05$.

LEA: leaves aqueous extract, LEM: leaves methanolic extract, STA: stem aqueous extract, STM: stem methanolic extract, SEA: seeds aqueous extract, and SEM: seed methanolic extract.

Note: "-" represents complete lysis of hemoglobin.

TABLE 2: Membrane stabilizing activity of Telferia occidentalis fractions.

\begin{tabular}{|c|c|c|c|c|c|}
\hline \multirow{2}{*}{ Extracts } & \multicolumn{5}{|c|}{ Concentration $(\mathrm{mg} / \mathrm{mL})$} \\
\hline & 0.5 & 1.0 & 1.5 & 2.0 & 2.5 \\
\hline$\overline{\text { LEA }}$ & $3.13 \pm 1.69$ & $9.41 \pm 0.86$ & $15.81 \pm 2.81$ & $20.13 \pm 0.59$ & $23.49 \pm 3.11$ \\
\hline LEM & $6.29 \pm 1.84$ & $14.94 \pm 2.56$ & $20.93 \pm 1.86$ & $25.42 \pm 0.10$ & $26.80 \pm 0.25$ \\
\hline STA & $28.41 \pm 4.31$ & $43.67 \pm 1.28$ & $50.17 \pm 2.16$ & $55.67 \pm 3.21$ & $60.14 \pm 1.15$ \\
\hline STM & $44.64 \pm 2.19$ & $53.22 \pm 4.33$ & $62.12 \pm 0.88$ & $66.00 \pm 2.11$ & $69.31 \pm 2.54$ \\
\hline SEA & $3.92 \pm 1.31$ & $12.16 \pm 1.77$ & $15.04 \pm 2.26$ & $25.21 \pm 1.07$ & $29.02 \pm 1.28$ \\
\hline SEM & $7.87 \pm 2.62$ & $19.03 \pm 1.89$ & $26.42 \pm 1.78$ & $30.17 \pm 1.22$ & $31.05 \pm 1.19$ \\
\hline Indomethacin & $30.21 \pm 1.07$ & $44.56 \pm 0.18$ & $64.13 \pm 3.01$ & $70.02 \pm 0.92$ & $78.94 \pm 2.88$ \\
\hline Ibuprofen & $26.26 \pm 1.99$ & $35.81 \pm 3.42$ & $49.38 \pm 1.43$ & $58.85 \pm 2.32$ & $61.33 \pm 1.12$ \\
\hline
\end{tabular}

LEA: leaves aqueous extract, LEM: leaves methanolic extract, STA: stem aqueous extract, STM: stem methanolic extract, SEA: seeds aqueous extract, and SEM: seed methanolic extract.

Gas Chromatography (GC). It was separated at $60^{\circ} \mathrm{C}$ at a flow rate of $1.83 \mathrm{~mL} / \mathrm{min}, 109.6 \mathrm{Kpa}$ pressure for $4.15 \mathrm{~min}$. Eluents were bombarded with a stream of protons from mass spectra (MS) and analyzed.

2.14. Statistical Analysis. Results were presented as mean \pm standard deviation (SD). Within and between the groups, comparisons were performed by analysis of variance (ANOVA) (using SPSS 17.0 computer software package). Significant differences were compared using Duncan Multiple Range Test (DMRT), and a probability level of less than 5\% $(p<0.05)$ was considered significant.

\section{Results}

3.1. In Vitro Antisickling Effects of Aqueous and Methanolic Extracts of Leaves, Seeds, and Stem of Telfairia occidentalis. Data on in vitro studies of the antisickling activity of T. occidentalis extracts carried out on blood samples collected from noncrisis sickle cell patients showed reversal of sickle cells at different rates and at different extract concentrations (Table 1). The leaves extracts (aqueous and methanolic) at $10 \mathrm{mg} \mathrm{mL}^{-1}$ exhibited the highest unsickling activity of $64.03 \% \pm 1.69$ and $57.79 \% \pm 2.61$, respectively, compared to the positive control (p-hydroxybenzoic acid) which showed activity of up to $72.25 \% \pm 1.85$.

Aqueous and methanolic crude extracts of the stem demonstrated a dose- and time-dependent increase in reverting sickled cells back to normal. However, the methanolic extract of seeds triggered partial lysis of erythrocytes at the maximum concentration of $10 \mathrm{mg} \mathrm{mL}^{-1}$, after 30 minutes of incubation. Complete lysis was seen between 60 and 120 minutes, by the effect of $10 \mathrm{mg} \mathrm{mL}^{-1}$ of methanolic seeds extract. This may imply that, at high concentration and over time, seeds extract of Telfairia occidentalis may have a cytotoxic effect (Table 1).

3.2. Membrane Stabilizing Effect of Extracts from the Different Plant Parts. Table 2 provides the membrane stabilizing activity of all fractions. Both aqueous and methanolic extracts of leaves and seeds of T. occidentalis exhibited a maximum inhibition (to haemolysis) of $27.05 \%$ and $32.24 \%$, respectively. The methanolic extract of the stem showed a more promising membrane stabilizing activity of $71.85 \%$ when compared with other fractions. The membrane stabilization activities of the standard drugs, Ibuprofen and Indomethacin, were $62.45 \%$ and $81.82 \%$, respectively.

\subsection{Partial Fractionation of Active Extract with Antisickling Activity}

3.3.1. Results of Column Chromatography Cum Thin Layer Chromatography. Sixty (60) fractions were obtained from column chromatography of the most active crude extract (aqueous leaves extract). A gradient mixture of hexane and 
TABLE 3: Peak antisickling effect of partially purified fractions of crude aqueous leaves extracts of Telfairia occidentalis (fluted pumpkin).

\begin{tabular}{|c|c|c|c|}
\hline \multirow{2}{*}{ Partially purified fractions } & \multicolumn{3}{|c|}{ Percentage (\%) of cells unsickled at $120 \mathrm{~min}$} \\
\hline & $10 \mathrm{mg}$ & $1 \mathrm{mg}$ & $0.1 \mathrm{mg}$ \\
\hline Fraction B & $55 \pm 2.92$ & $51 \pm 1.61$ & $43 \pm 1.75$ \\
\hline Fraction C & $70 \pm 3.39$ & $62 \pm 2.84$ & $54 \pm 1.56$ \\
\hline Fraction D & $65 \pm 2.66$ & $56 \pm 2.53$ & $44 \pm 3.44$ \\
\hline Fraction E & $52 \pm 1.46$ & $48 \pm 1.18$ & $41 \pm 4.89$ \\
\hline PABA $\left(5 \mathrm{mg} \mathrm{mL}^{-1}\right)$ & \multicolumn{3}{|c|}{$74 \pm 3.88$} \\
\hline Normal saline & \multicolumn{3}{|c|}{$7 \pm 0.69$} \\
\hline
\end{tabular}

TABLE 4: GC-MS analysis of fraction C.

\begin{tabular}{|c|c|c|c|c|}
\hline S/no & Name of compound & Chemical formula & M. wt. & RI \\
\hline$(1)$ & Pentadecanoic acid, 14-methyl ester & $\mathrm{C}_{17} \mathrm{H}_{34} \mathrm{O}_{2}$ & 270 & 619 \\
\hline (2) & Octadecanoic acid & $\mathrm{C}_{18} \mathrm{H}_{36} \mathrm{O}_{2}$ & 283 & 749 \\
\hline (3) & Hexadecanoic acid & $\mathrm{C}_{16} \mathrm{H}_{32} \mathrm{O}_{2}$ & 256 & 648 \\
\hline$(4)$ & 9-Octadecadienoic acid (Z)-, 2,3-dihydroxypropyl ester & $\mathrm{C}_{21} \mathrm{H}_{40} \mathrm{O}_{4}$ & 356 & 756 \\
\hline$(5)$ & $\alpha$-Campholene aldehyde & $\mathrm{C}_{19} \mathrm{H}_{16} \mathrm{O}$ & 152 & 1123 \\
\hline (6) & Cyclohexanespiro- $5^{\prime}, 4^{\prime}$-methyl-2' - phenyl-2' -oxazoline & $\mathrm{C}_{15} \mathrm{H}_{19} \mathrm{NO}$ & 229 & 947 \\
\hline (7) & $\alpha$-Phellandrene & $\mathrm{C}_{10} \mathrm{H}_{16}$ & 136 & 1243 \\
\hline (8) & 16-Octadecenoic acid & $\mathrm{C}_{19} \mathrm{H}_{36} \mathrm{O}_{2}$ & 296 & 718 \\
\hline (9) & Borneol & $\mathrm{C}_{10} \mathrm{H}_{18} \mathrm{O}$ & 154 & 1164 \\
\hline
\end{tabular}

ethyl acetate was used as eluent. Fractions with the same number of spots, $R_{f}$ values, and the same colour under UV light were pooled together and used to test for antisickling activity.

3.4. GC-MS Analysis. The GC-MS analysis of purified fraction that showed peak antisickling activity (Fraction C) revealed some associated bioactive components. Their molecular weight, chemical formula and retention index are shown in Table 4.

\section{Discussion}

Results obtained from this research indicated that in vitro antisickling action of extracts (leaves, stem, and seeds), especially the aqueous leaves extract, was rapid. A $64.03 \%$ reversal of sickle cells was observed in 120 minutes by the effect of the crude leaves extract of T. occidentalis. Partial purification (fractionation) of leaves extract exhibited a distinctive increase in antisickling activity, with fraction C (Table 3) showing the highest level of reversal of sickled erythrocytes (74\%). The higher antisickling activity shown by the partially purified extract is attributed to the fact that bulky interfering molecules such as impurities, artifacts, and contaminants have been eliminated by the purification process, thereby leaving behind the pure bioactive components.

Bioactive compounds such as $\alpha$-phellandrene, borneol, 16-octadecenoic acid, 9-octadecadienoic acid (Z)-, 2,3-dihydroxypropyl ester, pentadecanoic acid, 14-methyl ester, and $\alpha$-campholene were elucidated using Gas Chromatography Linked Mass Spectroscopy (GC-MS) (Table 4).
Alpha-Phellandrene ( $\alpha$-phellandrene) has been reported to inhibit inflammation [23], promote immune response [24], and fight infections [25]. Also, borneol, pentadecanoic acid, 16-octadecenoic acid, 9-octadecadienoic acid (Z)-, 2,3-dihydroxypropyl ester, and $\alpha$-campholene aldehyde have been linked with analgesic, antibacterial, antioxidant, antipyretic, antispasmodic, and sedative activity [26]. The aforementioned conditions are central to sickle cell disease crisis, thereby suggestive of the fact that T. occidentalis may presage a therapeutic potential in SCD. If this action can be reproduced in vivo, then the extract may as well hold a lot of promise in the treatment of sickle cell disease.

Depending on its half-life, it would be expected that its periodic administration would reduce both frequency and duration of crises.

Pathophysiology of sickle cell disease has been attributed to both sickle hemoglobin and erythrocyte-membrane behavior [27]. Membrane stabilizing effect of various concentrations of extracts (leaves, stem, and seeds) on sickle red blood cells revealed an overall maximum activity of $71.85 \pm$ $0.001 \%$ in the stem methanolic extract and minimum activity of $22.60 \pm 0.003 \%$ in aqueous leaves extract. The results showed that both extracts contained principles that protected the erythrocyte membrane effectively. Membrane stabilizing activity was observed to be plant part and concentrationdependent. Also, the aqueous leaves extract showed the least protection on erythrocyte membrane.

On the basis of these results, it could be inferred that the aqueous and methanolic extracts of leaves, stem, and seeds of T. occidentalis contained principles that were capable of stabilizing sickle erythrocyte membrane against heat and hypotonic-induced lysis. 


\section{Conclusion}

The results of this study scientifically validated the in vitro potential of $T$. occidentalis in the management of sickle cell disease.

\section{Abbreviations}

SCD: $\quad$ Sickle cell disease

TLC: $\quad$ Thin Layer Chromatography

$R_{f}: \quad$ Retention factor

ANOVA: Analysis of variance

DMRT: Duncan Multiple Range Test

HbSS: Homozygous sickle cell disease

HREC: Health Research Ethical Committee

RBC's: Red blood cells

LEA: Aqueous leaves extract

LEM: Methanolic leaves extract

SEA: Aqueous seed extract

SEM: Methanolic seed extract

STA: Aqueous stem extract

STM: Methanolic stem extract and

Para-hydroxybenzoic acid (PABA).

\section{Disclosure}

Present address of Samuel Atabo: Department of Biological Science, University of Agriculture, Makurdi, Benue State, Nigeria.

\section{Competing Interests}

The authors declare that there are no competing interests regarding the publication of this paper.

\section{Acknowledgments}

This work was self-funded with support from family.

\section{References}

[1] R. E. Ware, "Is sickle cell anemia a neglected tropical disease?" PLoS Neglected Tropical Diseases, vol. 7, no. 5, Article ID e2120, 2013.

[2] F. B. Piel, S. I. Hay, S. Gupta, D. J. Weatherall, and T. N. Williams, "Global burden of sickle cell anaemia in children under five, 2010-2050: modelling based on demographics, excess mortality, and interventions," PLoS Medicine, vol. 10, no. 7, Article ID e1001484, 2013.

[3] World Health Organization, "Thalassaemia and sickle cell disease," http://www.genetics.edu.au/genetics/Genetic-conditionssupport-groups/FS34KBS.pdf.

[4] World Health Organization, "Pain and penury of sickle cell disease not beyond science," 2012, http://www.vanguardngr .com/2012/06/pain-and-penury-of-sickle-cell-disease-not-beyond-science/.

[5] P. T. Mpiana, V. Mudogo, K. N. Ngbolua, D. S. T. Tshibangu, O. M. Shetonde, and M. B. Mbala, "In vitro antisickling activity of anthocyanins from Ocimum basilicum L. (Lamiaceae)," International Journal of Pharmacology, vol. 3, no. 4, pp. 371-374, 2007.
[6] A. S. Mehanna, "Sickle cell anemia and antisickling agents then and now," Current Medicinal Chemistry, vol. 8, no. 2, pp. 79-88, 2001.

[7] R. Eliot, M. Davies, and D. J. Hamse, "Dermatomyositis-like eruption with long-term hydrourea," British Journal of Dermatology, vol. 17, pp. 56-60, 2006.

[8] G. I. Ekeke and F. O. Shode, "Phenylalanine is the predominant antisickling agent in Cajanus cajan seed extract," Planta Medica, vol. 56, no. 1, pp. 41-43, 1990.

[9] A. O. Akinsulie, E. O. Temiye, A. S. Akanmu, F. E. A. Lesi, and C. O. Whyte, "Clinical evaluation of extract of Cajanus cajan (Ciklavit ${ }^{\circledR}$ ) in sickle cell anaemia," Journal of Tropical Pediatrics, vol. 51, no. 4, pp. 200-205, 2005.

[10] K. D. Thomas and B. Ajani, "Antisickling agent in an extract of unripe pawpaw fruit (Carica papaya)," Transactions of the Royal Society of Tropical Medicine and Hygiene, vol. 81, no. 3, pp. 510511, 1987.

[11] C. M. Ogunyemi, A. A. Elujoba, and M. A. Durosimi, "Antisickling properties of Carica papaya Linn," Journal of Natural Products, vol. 1, pp. 56-66, 2008.

[12] N. O. Imaga, G. O. Gbenle, and V. I. Okochi, "Antisickling property of Carica papaya leaf extract," African Journal of Biochemistry Research, vol. 3, no. 4, pp. 102-106, 2009.

[13] E. A. Sofowora and W. A. Isaacs, "Reversal of sickling and crenation in erythrocytes by the root extract of Fagara zanthoxyloides," Lloydia, vol. 34, no. 4, pp. 383-385, 1971.

[14] E. A. Sofowora, "Isolation and characterization of an antisickling agent from the root of Fagarazanthoxyloides," in Proceedings of a Symposium Fagara and the Red Blood Cell, pp. 79-87, University of Ife Press, 1979.

[15] A. O. Fasuyi, "Nutritional potentials of some tropical vegetable leaf meals: chemical characterization and functional properties," African Journal of Biotechnology, vol. 5, no. 1, pp. 49-53, 2006.

[16] M. S. Toyin, A. O. Luqman, and A. O. Wahab, "Aqueous extract of Telfairia occidentalis leaves reduces blood sugar and increases haematological and reproductive indices in male rats," African Journal of Biotechnology, vol. 7, no. 14, pp. 2299-2303, 2008.

[17] O. A. Oyewole and M. E. Abalaka, "Antimicrobial activities of Telfairia occidentalis(fluted pumpkins) Leaf extract against selected intestinal pathogens," Journal of Health Science, vol. 10, pp. 119-127, 2012.

[18] E. B. James, W. K. Joe, and C. H. Chadwick, "Organizational research: determining appropriate sample size in survey," Research Information Technology, Learning, and Performance Journal, vol. 19, no. 1, pp. 43-50, 2001.

[19] T. Oduola, F. A. A. Adeniyi, E. O. Ogunyemi, I. S. Bello, and T. O. Idowu, "Antisickling agent in an extract of unripe pawpaw (Carica papaya): is it real?" African Journal of Biotechnology, vol. 5, no. 20, pp. 1947-1949, 2006.

[20] A. Egunyomi, J. O. Moody, and O. M. Eletu, "Antisickling activities of two ethnomedicinal plant recipes used for the management of sickle cell anaemia in Ibadan, Nigeria," African Journal of Biotechnology, vol. 8, no. 1, pp. 020-025, 2009.

[21] O. S. Falade, I. O. Otemuyiwa, A. Oladipo, O. O. Oyedapo, B. A. Akinpelu, and S. R. A. Adewusi, "The chemical composition and membrane stability activity of some herbs used in local therapy for anemia," Journal of Ethnopharmacology, vol. 102, no. 1, pp. 15-22, 2005.

[22] P. Usha Rani and P. Devanand, "Efficiency of different plant foliar extracts on grain protection and seed germination in 
maize," Research Journal of Seed Science, vol. 4, no. 1, pp. 1-14, 2011.

[23] J.-J. Lin, J. U.-H. Lin, S.-C. Hsu et al., "Alpha-phellandrene promotes immune responses in normal mice through enhancing macrophage phagocytosis and natural killer cell activities," In Vivo, vol. 27, no. 6, pp. 809-814, 2013.

[24] G. İşcan, N. Kirimer, F. Demirci, B. Demirci, Y. Noma, and K. H. C. Başer, "Biotransformation of $(-)-(R)-\alpha$-phellandrene: antimicrobial activity of its major metabolite," Chemistry \& Biodiversity, vol. 9, no. 8, pp. 1525-1532, 2012.

[25] Dr. Duke's Phytochemical and Ethnobotanical Databases, http://www.ars-grin.gov/duke/chem-activities.html.

[26] P. T. Mpiana, K. N. N. Ngbolua, M. T. Bokota et al., "In vitro effects of anthocyanin extracts from Justicia secunda Vahl on the solubility of haemoglobin $S$ and membrane stability of sickle erythrocytes," Blood Transfusion, vol. 8, no. 4, pp. 248-254, 2010.

[27] G. Kumar, K. Jayaveera, C. Ashok, T. Bharathi, S. Umachigi, and S. Vrushabendra, "Evaluation of antioxidant and antiacne properties of terpenoidal Fraction of Hemidesmusindicus (Indian sarsaparilla)," International Journal of Aesthesia and Anti-aging Medicine, vol. 11, pp. 113-118, 2008. 

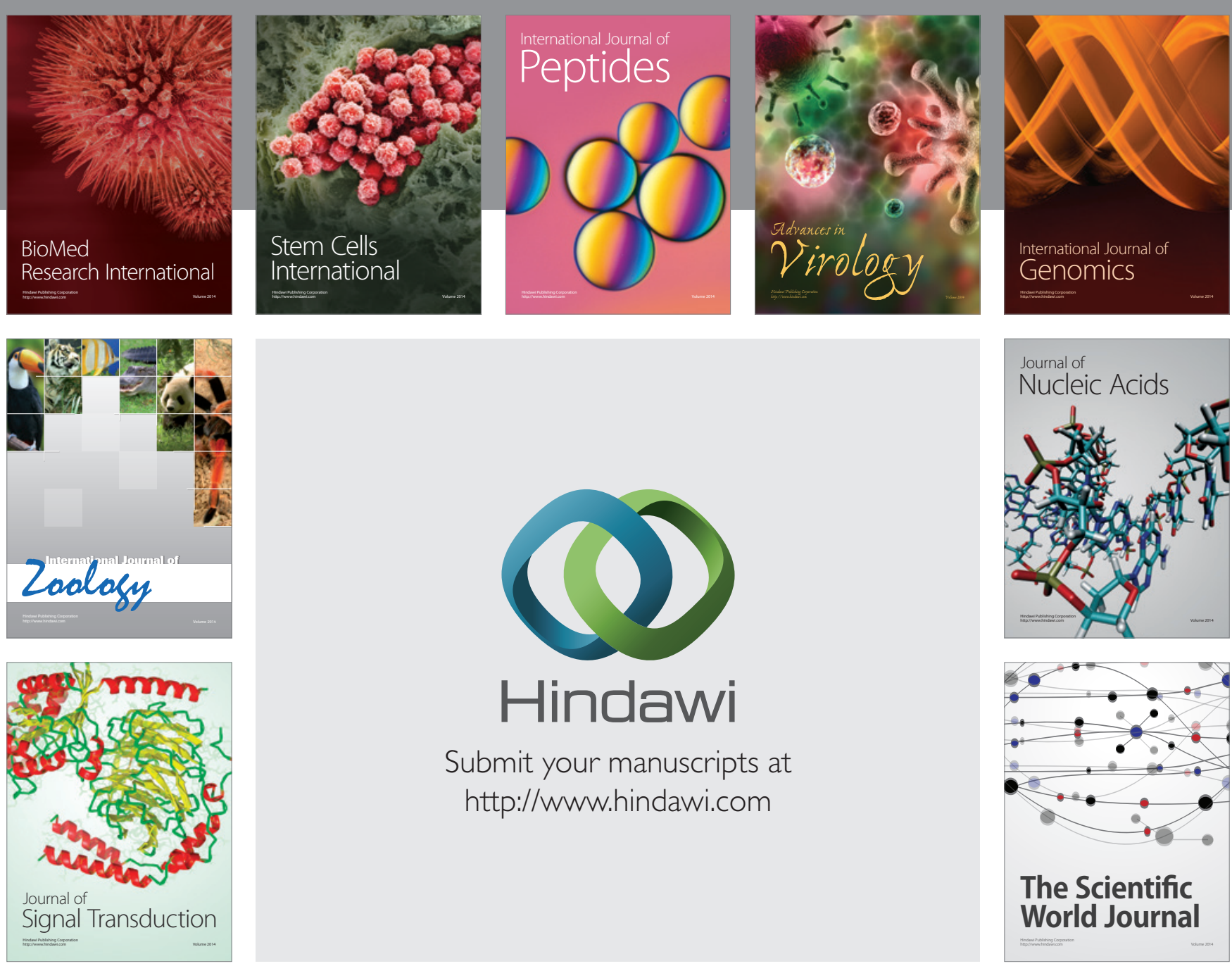

Submit your manuscripts at

http://www.hindawi.com
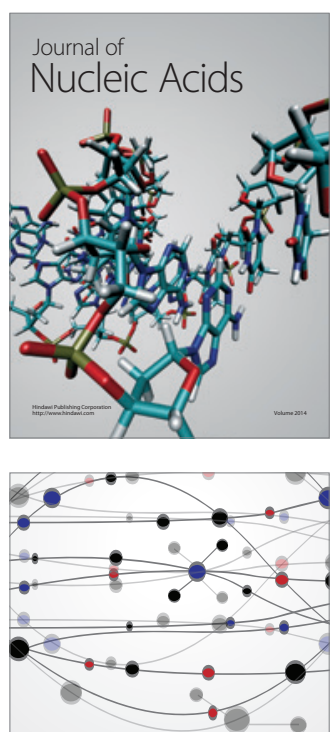

The Scientific World Journal
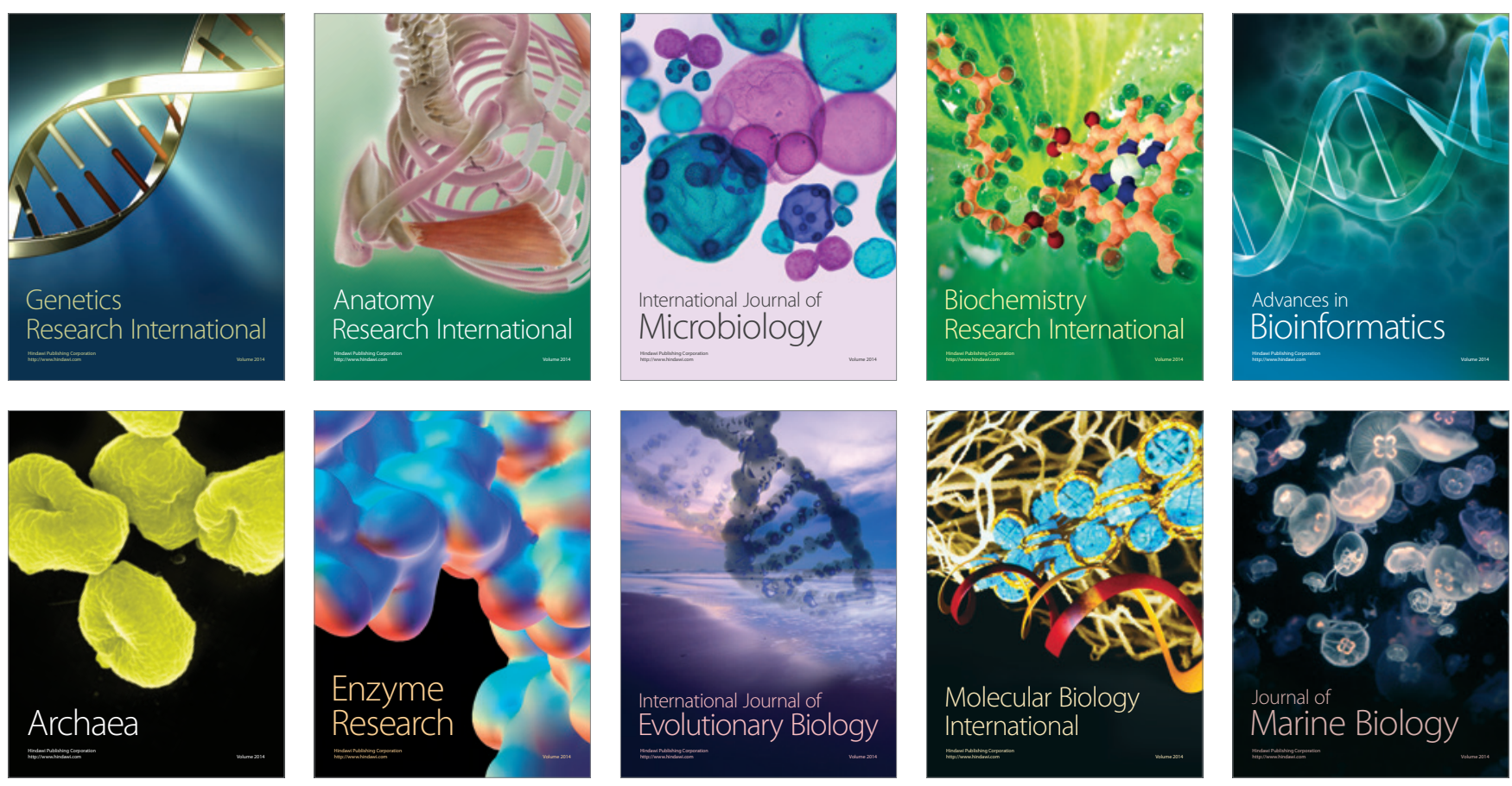